\title{
Is Economic Freedom the Hidden Path to Social Justice?
}

\section{Jeremy Horpedahl}

University of Central Arkansas

Jeremy Jackson

North Dakota State University

\section{David Mitchell}

University of Central Arkansas

\begin{abstract}
How can societies advance social justice? Research on economic freedom addresses many social justice goals, including social tolerance and protection of minority rights, promotion of democracy and political freedoms, and income equality. We survey the academic literature on these topics and find that economic freedom can advance social justice goals in some cases. For income equality the resulted are mixed, but the other goals have a clear relationship with economic freedom. Based on these results, social justice advocates may want to embrace economic freedom to achieve goals such as tolerance, minority rights, democracy, and political freedom.
\end{abstract}

\section{JEL Codes: D63, I30, O15}

Keywords: social justice, economic freedom, social tolerance, political freedom, income inequality

\section{Introduction}

The social justice movement attempts to address some of the most pressing social, political, and economic issues of our time. But as with any social movement, there is often a large gap between identifying problems and finding solutions. Sometimes the solutions are found in unexpected places. Could the solution to many social justice issues be found in a most unexpected place: expanding economic freedom? In this paper, we suggest that, in many cases, economic freedom contributes to social justice goals, which may be surprising since the social justice movement is often seen as being opposed to markets. 
The first story Cowen and Tabarrok (2018) tell in their principles of microeconomics textbook involves a social justice problem that was solved in an unexpected way: by changing the incentives. The transportation of British convicts to the penal colony of Australia in the eighteenth century caused a scandal: on some ships, up to onethird of the convicts were dying before reaching Australia. Though the passengers were criminals, citizens of a civilized society such as Great Britain knew that a society is measured by how its people treat all humans, even those convicted of crimes. The solution to the problem: pay ship captains for the number of prisoners that survive the journey rather than the number that board the ship.

Today, human trafficking and slavery are a major focus of the social justice movement. Millions of people are trapped in these circumstances (International Labour Organization 2017). What is the solution? Is this the dark side of globalization and economic freedom, as increasingly connected rich and poor countries interact with one another?

Researchers have addressed this exact question. Heller et al. (2018) use data from the Fraser Institute's Economic Freedom of the World index to bring scientific rigor to the question. They reach two important conclusions. First, there is no statistical relationship between economic freedom and human trafficking. In other words, countries with more economic freedom do not have more trafficking. There is no dark side of economic freedom in this case. But this finding suggests that economic freedom does not reduce trafficking, either. Depending on one's prior beliefs, this result may or may not be surprising.

The paper's second conclusion may be just as important: countries with greater economic freedom are more likely to institute and enforce policies designed to combat human trafficking. Enactment of credible policies is one of the social justice movement's main intermediate goals for achieving its ultimate ends.

The human-trafficking example illustrates how empirical research and measures of economic freedom can help advance social justice. This way of thinking is how this paper approaches the question, "Can economic freedom be a tool for advancing social justice?" Before we address this question more directly, however, we need to more clearly define the term "social justice." 


\section{Defining Social Justice and Economic Freedom}

Both "social justice" and "economic freedom" are loaded terms with multiple meanings. To carefully review the literatures connecting the two, it is important to precisely define the two concepts.

\section{A. Social Justice}

While Hayek (1976) argued that the concept of social justice was a "mirage," at least in terms of distributive justice or income equality, many scholars since have tried to more precisely define the term. For a concise definition of social justice, we turn to the introduction of Tomasi (2012). Tomasi states that "[social] justice requires that institutions be designed so that the benefits they help produce are enjoyed by all citizens, including the least fortunate" (Tomasi 2012, xiv). Much like Tomasi (2012), we contend that social justice and market liberalism need not be in opposition. While Tomasi gives a philosophical defense of the system of "market democracy," we instead focus on the empirical outcomes associated with the system-more specifically, economic freedom-that are also associated with the social justice movement's goals.

While Tomasi's definition is to be credited for its brevity, some scholars more closely aligned with the social justice movement might object to its lack of nuance. Bell (2016, p. 3) offers a definition of social justice that is less concise but shows the term's breadth:

Social justice is both a goal and a process. The goal of social justice is full and equitable participation of people from all social identity groups in a society that is mutually shaped to meet their needs. The process for attaining the goal of social justice should also be democratic and participatory, respectful of human diversity and group differences, and inclusive and affirming of human agency and capacity for working with others to create change. Domination cannot be ended through coercive tactics that recreate domination in new forms.... Forming coalitions and working collaboratively with diverse others is an essential part of social justice.... Our vision for social justice is a world in which the distribution of resources is equitable and ecologically sustainable, and all members are physically and psychologically safe and secure, recognized, and treated with respect. We envision a world in which individuals are both self-determining 
(able to develop their full capacities) and interdependent (capable of interacting democratically with others).

Social justice is also closely related to the capabilities approach of Sen (1989) and Nussbaum (2000). Stiglitz, Sen, and Fitoussi (2009) argue that the capabilities approach "has strong roots in philosophical notions of social justice" (p. 42). This broader approach to measuring human progress above and beyond GDP leads us to a better understanding of social justice objectives.

First, institutions should be oriented so all members of a society-including the least fortunate and most marginalized members, and regardless of social identity group_-are included and respected and have their human agency affirmed. A society that pursues social justice will tolerate diverse viewpoints, and individuals will trust each other as they work together to achieve a common end. Second, social justice requires voluntary (as opposed to coercive) democratic participation and processes. Political cronyism and corruption propagate the power differentials social justice seeks to undo.

Last, social justice is dedicated to the equitable distribution of resources. Chief among societal resources are income and wealth. To answer the question of whether economic freedom can further social justice, we examine the three broad groups of social justice objectives: tolerance and protection of minority rights; democracy and political freedom; and income equality. For each of these three groups of goals, we find that economic freedom may help to advance them. We caution that this is not always the case and that sometimes the relationship is complicated. The most challenging area to assess is income inequality. The literature is very mixed on this question, with much of it suggesting that economic freedom increases income inequality, though this finding is not universal. Causation is also difficult to establish in many cases.

Even with the mixed results for income inequality, a clear lesson for social justice policy can be drawn: while some areas of economic freedom may increase inequality, others may reduce it. For example, highly progressive income taxes reduce a country's economic freedom score while potentially reducing inequality. However, other areas of economic freedom, such as the freedom to trade internationally, appear to reduce inequality in some cases. If specific policy changes are important goals of the social justice movement, understanding this relationship in detail is crucial. Convincing 
countries to move policy in the wrong direction could backfire and lead to less social justice.

\section{B. Economic Freedom}

Before proceeding to our survey of the research, a brief discussion of economic freedom and its measurement is important. Any interpretation of the empirics of economic freedom must be based on its assigned definition. Here we borrow the definition provided by Gwartney et al. (2018):

The cornerstones of economic freedom are personal choice, voluntary exchange, open markets, and clearly defined and enforced property rights. Individuals are economically free when they are permitted to choose for themselves and engage in voluntary transactions as long as they do not harm the person or property of others. When economic freedom is present, the choices of individuals will decide what and how goods and services are produced. Put another way, economically free individuals will be permitted to decide for themselves rather than having options imposed on them by the political process or the use of violence, theft, or fraud by others. (Gwartney et al. 2018, pp. 1-2)

The Fraser Institute's Economic Freedom of the World index (Gwartney et al. 2018) measures, for 162 countries and territories, the consistency of the institutions within a country with the ideals of economic freedom. Higher scores indicate greater economic freedom. While competing indexes of economic freedom have been published, the EFW index is the most heavily cited in the academic literature and is the one used by most of the studies we cite. Its methodology is data driven, with no subjective valuations, and is based on data in five areas of economic freedom: (1) size of government, (2) legal system and property rights, (3) sound money, (4) freedom to trade internationally, and (5) regulation of credit, labor, and business.

The size of government component uses data on government consumption, transfers and subsidies; government enterprises and investment; and top marginal tax rates to measure the degree to which a country allows freedom of personal choice through markets versus centralized decision making. The legal system and property rights component takes in data from nine indicators reflecting adherence to the rule of law, the security of property rights, and an 
impartial justice system. The sound money component is based on the idea that citizens need access to sound money as a store of value and as a means to transact. The measurement is based on four subcomponents relating to inflation and the freedom to own foreigncurrency bank accounts. The freedom to trade internationally component uses data in four areas to measure freedom to trade with people in foreign countries and focuses primarily on various types of trade restrictions. Finally, the regulation of credit, labor, and business component measures regulatory restrictions of voluntary exchange.

The other major economic freedom measurement is published by the Heritage Foundation and is called the Index of Economic Freedom (Miller, Kim, and Roberts 2018). The two world indices are similar in what they measure, with some differences in the variables used and category weightings. While the majority of papers we review use the Fraser index, some use the Heritage index as well. The Fraser Institute also publishes the Economic Freedom of North America index (Stansel, Torra, and McMahon 2018). This index is modeled closely on the Economic Freedom of the World index but measures economic freedom for each of the US and Mexican states in addition to the Canadian provinces.

\section{The Relationship between Economic Freedom and Measures of Social Justice}

We review the literature on the relationship between economic freedom and several measures of social justice. In particular, we discuss three main areas of interest to social justice advocates: (A) tolerance and protection of minority groups; (B) democracy, political rights, and civil liberties; and (C) income inequality. The literature on economic freedom and income inequality, while nonconclusive, clearly demonstrates that increased economic freedom promotes increased tolerance for minorities as well as broad civil liberties and political freedoms.

\section{A. Tolerance and Protection of Minority Groups}

The concept of social justice requires, in keeping with Rawlsian philosophy, that society care for its least well off and most vulnerable members. These members include those who identify with various racial, ethnic, gender, and sexual groups that are in minority positions relative to the economically and politically powerful. A liberal society oriented toward social justice would be focused on including members of said groups, as revealed by attitudes of tolerance. 
Research largely demonstrates that environments characterized by racial, ethnic, and cultural heterogeneity will have weaker generalized social trust (Stolle, Soroka, and Johnston 2008). Homogeneity breeds trust and social capital (Costa and Kahn 2003). It is easy for people to have generalized trust in a population that shares the same values, culture, and appearance. Yet, in such homogenous environments, members of various minority groups are also more likely to be disenfranchised, isolated, disadvantaged, and discriminated against (Kymlicka 1995; Simpson and Yinger 1985). These research findings do not mean we should implement policies that seek to increase social capital and social trust by making a population more homogeneous. Principles of common decency, and the values of social justice more generally, preclude such behavior.

Social trust and social capital more broadly indicate acceptance and tolerance toward minority groups (Sullivan and Transue 1999; Cigler and Joslyn 2002; Persell, Green, and Gurevich 2001). Social trust and social capital are linked to a number of positive outcomes including economic growth (Knack and Keefer 1997), democracy (Inglehart 1999), happiness (Bjørnskov 2003), low crime (Buonanno, Montolio, and Vanin 2009; Lederman, Loayza, and Menendez 2002), and health (Kawachi, Subramanian, and Kim 2008). However, because social capital cannot be redistributed by taking it from one person and giving it to another, social capital, while consistent with many social justice goals, is fundamentally incompatible with the goal of equal distribution (Jackson and Palm 2017).

Niclas Berggren along with several coauthors, most prominently Therese Nilsson, has been prolific in researching societal attitudes toward minorities, especially how economic freedom affects those attitudes. This line of research began with Berggren (1999), which focuses on the effects of economic freedom and income inequality. However, it is in Berggren and Jordahl (2006) that the effects of economic freedom on social attitudes, and social trust in particular, come into focus.

Berggren and Jordahl (2006) find empirical evidence that establishes a positive and causal link between economic freedom and general social trust. Their research makes use of the generalized-trust question from the World Values Survey as well as the Fraser Institute's Economic Freedom of the World index. Generalized trust is measured as the percentage of respondents in a country that agree that "most people can be trusted." Berggren and Jordahl (2006) conclude that policies promoting economic freedom, primarily 
through the channels of the legal structure and the security of property rights, can be a tool to increase generalized social trust and social capital.

Using the World Values Survey, which covers ninety-eight countries, from 1994 through 2014, De Soysa, Jakobsen, and Holum (2017) find that a country's Heritage Economic Freedom index ranking has little impact on the trust individuals place in decision makers (the legislature or government) when using linear multilevel models. Their regressions result in small, mostly nonsignificant coefficients, though the coefficients are negative. However, this null effect hides a more detailed interaction effect that demonstrates that for Western countries, there is a positive association between economic freedom and social trust. Another study (Jackson, Carden, and Compton 2015) could not find a relationship between economic freedom and social capital in the United States. However, as is further pointed out in Jackson (2017a), this apparent lack of relationship is largely due to a shortcoming in the measure of social capital used, which does not have a trust dimension and instead focuses on measures of civic engagement.

While the positive effect of economic freedom on generalized trust is interesting, generalized trust is only tangentially related to attitudes toward minority and disadvantaged groups. In subsequent papers, Berggren and Nilsson tackle attitudes of tolerance directly. Berggren and Nilsson (2013) find that economic freedom is positively related to tolerance toward gay people both at a point in time and over time. They also find that economic freedom appears to be unrelated to racial tolerance. Berggren and Nilsson (2014) find that social trust mediates the relationship between economic freedom and tolerance toward gay people so that the effect of economic freedom is largest when trust is also large. While the previous studies all use international data, Berggren and Nilsson (2016) explore the effect of economic freedom on racial, religious, political, and sexual attitudes in the United States making use of the Economic Freedom of North America index. They uncover robust effects of a less progressive tax system and lower marginal tax rates on increased tolerance toward gay people, communists, and atheists.

In addition to the effect of economic freedom on social trust and tolerance, a well-established literature demonstrates a positive effect of economic freedom on happiness (Jackson 2017b) and subjective well-being more broadly (Veenhoven 2000). Gehring (2013) finds a positive and significant effect of economic freedom on happiness 
that is moderated in part by attitudes of tolerance. Societies that display more tolerance obtain bigger increases in well-being from increased economic freedom. Nikolaev and Bennett (2017) find an effect of economic freedom on more emotional aspects of subjective well-being such as increased positive affect and decreased negative affect.

Meanwhile, Bennett and Nikolaev (2017) demonstrate that economic freedom reduces inequality of well-being using a robust set of inequality measures. This finding demonstrates that people actually report being happier under institutions of greater economic freedom and that the benefits of economic freedom on well-being aren't falling only on those in the upper ranks of the happiness distribution. Enhanced subjective well-being, along with the psychological resources that come with it, is consistent with the psychological safety and security objectives of social justice. Nikolaev (2014) shows that the Human Development Index - a measure of capabilities-as well as measures of health, education, and civic engagement, are related to higher levels of economic freedom. This result generally holds even after controlling for income.

\section{B. Democracy, Political Rights, and Civil Liberties}

While social justice is often defined in terms of outcomes, various components of the political process could be included in a robust definition. For example, Rawls (2001) identifies political liberties as a component of his first principle of justice. Political liberties include equal rights to hold office, affect the outcome of elections, and similar rights that we might generally call democracy or political freedom. Other political liberties include the freedoms of speech, press, and assembly. Another democratic component of social justice is the absence of corruption or cronyism.

The previous section showed that economic freedom can lead to increased tolerance, trust, and well-being. Empirically, when countries' incomes rise, not just the average income rises but also the income of the poorest quintile rises proportionally (Dollar and Kraay 2002). Each of these effects has also been demonstrated to contribute to better-functioning democratic institutions (Inglehart 1999; Sullivan, Piereson, and Marcus 1993; Sullivan and Transue 1999). Is there a further connection between political freedoms and economic freedoms?

One relevant line of research looks at a slightly different question: whether political or economic freedoms lead to beneficial outcomes, 
such as economic growth. But much of this research also comments on the relationship between economic and political freedom, including whether one causes the other. Dawson (1998) suggests that changes in economic freedom explain subsequent levels of political freedom and civil liberties. Wu and Davis (1999) argue that economic freedom is necessary for high incomes, and political freedom follows economic prosperity.

In contrast, Davis (2003) uses Granger causality tests to show that political and individual liberties cause economic freedom. Aixala and Fabro (2009) decompose political freedom into civil liberties and political rights; they also perform Granger tests. They, too, find that civil liberties and political rights cause economic freedom, but also that a virtuous circle exists: economic freedom causes economic growth, which in turn expands civil liberties, which promote further economic freedom.

One paper that directly discusses the relationship between economic and political freedom is Lawson and Clark (2010). The authors investigate the "Hayek-Friedman hypothesis" (from Hayek 1944 and Friedman 1962), which they summarize as follows: "societies with high levels of political freedom must also have high levels of economic freedom." Lawson and Clark use the EFW index to argue that it is rare to find societies with high levels of political freedom that don't also have high levels of economic freedom (using data going back to 1972). Further, these rare cases are diminishing over time, as many countries that temporarily have had low political but high economic freedom have moved to a higher level of political freedom in the cases they examine. They argue that this case-study method is superior to the tests used in earlier papers because it does not attempt to fit countries to a line (as in regression analysis) but instead looks at case studies.

De Soysa and Vadlammanati (2013) look at a related issue: the relationship between economic freedom and human rights. They find that promarket economic reforms, measured as changes in the EFW index, improve human rights. The results are substantively large, even when controlling for measures of wealth and democracy, and the authors attempt to control for endogeneity as well. In a more recent paper (De Soysa and Vadlamannati 2017), the same authors demonstrate that high ethnic and cultural diversity is associated, possibly causally, with high levels of economic freedom. They find that diverse and politically democratic countries are more likely to have a higher level of economic freedom. 
Just as human rights protections for racial and ethnic groups are an important social justice goal, so are women's rights. Take the issue of secondary schooling for women (Unterhalter 2012), which is important to social justice because women and girls are disadvantaged in many societies by receiving less education than their male counterparts. Using data from 109 countries from 1972 through 2011, Feldmann (2017) finds that increases in economic freedom lead to higher rates of secondary schooling, especially for women.

Freedom of the press and media are also key components of democracy: they allow the public to be informed about important political issues. Bjørnskov (2018) tests a variant of the HayekFriedman hypothesis and finds that increases in economic freedom are followed by increases in press freedom.

Several papers have also looked at the relationship between economic freedom and corruption. Corruption can be defined as using a position of political power for personal gain, and thus it is in conflict with social justice. Sandholtz and Koetzle (2000) use the Freedom House indicators, a third measure of economic freedom that has since been discontinued, to show that state control of the economy leads to more corruption as measured by Transparency International. Graeff and Melkhop (2001) use the Fraser Institute's Economic Freedom of the World index for their economic freedom variables, but also deconstruct the index into its components. They find different results for rich and poor countries, and while many areas of economic freedom reduce corruption, a few do not. For example, in poor countries, the freedom to own foreign currencies increases corruption, and in rich countries, bigger governments are associated with less corruption (though the authors doubt this is causal).

Goel and Nelson (2005) compare the effects of economic and political freedom on corruption. They find that economic freedom is a greater deterrent of corruption than political freedom isspecifically, that more freedom in terms of monetary policy, financial market regulation, and black market activity is related to less corruption. Saha and Su (2012) examine the effect of the interaction between democracy and economic freedom on corruption. They find that higher levels of economic freedom reduce corruption, but they do so more effectively when levels of democracy are also high. In contrast, democracy does not reduce corruption when economic freedom levels are low. 
One symptom of corruption and a lack of political and civil liberties is social unrest potentially leading to civil war (Thoms and Ron 2007). Using logit analysis, de Soysa and Fjelde (2010) find that countries with more economic freedom are less likely to be involved in intrastate civil conflict, the victims of which are often children and infants (Navia and Zweifel 2003). De Soysa (2016) shows that economic freedom, not democracy, is associated with a lower risk of civil war and societal insecurity.

\section{Income Inequality}

The common Rawlsian approach (Rawls 1971) maximizes the leastwell-off individual's welfare even at the expense of many others. For example, this approach argues that "the primary goal of most social protection interventions is to protect minimum subsistence in lowincome households" (Devereux, McGregor, and Sabates-Wheeler 2011). Nevertheless, it is uncertain whether economic prosperity enhances quality of life (Diener and Diener 1995). The economic freedom literature does not simplistically use national GDP per capita as a proxy for its welfare function. Grubel (1998) and the first Economic Freedom of the World report (Gwartney et al. 1996) show that the poorest quintile in less-free societies is worse off than the poorest quintile in more-free societies. Bernstein et al. (2000) perform a similar analysis at the US state level. They remind readers that data for very high income earners are suppressed for privacy reasons in the United States. Imputation is required for top earners, and that may induce error.

Clark and Lawson (2008) use the Fraser Institute's Economic Freedom of the World index to look at the relationship among economic freedom, taxes, and inequality. They find a relationship between progressive taxation (high top marginal tax rates) and reduced inequality. However, they also find that higher scores on property rights, sound money, trade openness, and government size correlate with less inequality. By primarily looking at correlations, the paper identifies a common theme in the subsequent literature: different components of economic freedom have different relationships with income inequality. It may be impossible to state definitively the relationship between economic freedom and income inequality.

Scully (2002), using structural and reduced-form models, finds a positive and significant but relatively small trade-off between economic growth and income inequality from 1960 to 1990. Scully 
further finds that when government expenditure is separated into productive and nonproductive components, the coefficient of productive expenditures is positive but insignificant, while that of nonproductive expenditures is negative and significant.

Using estimates for a fixed-effects model of country-level Gini coefficients as a function of economic freedom along with relevant control variables, ${ }^{1}$ Carter (2007) finds that over a broad range of freedom, the estimated relationship between economic freedom and income inequality is positive and statistically significant. His data come from two main sources: the UNU-WIDER World Income Inequality Database Version 2.0a and the Fraser Institute's Economic Freedom of the World index. He controls for per capita income, political structure, education, demographics, and industrial composition.

Bergh and Nilsson (2010) study eighty countries from 1970 to 2005 and find that under a variety of specifications including GMM (generalized method of moments), increasing economic freedom increases inequality in many cases. However, they find that monetary reforms, legal reforms, and political globalization do not increase inequality.

Bennett and Nikolaev (2017) examine six different measures of income inequality with up to 112 countries from 1970 to 2010. By studying the Standardized World Income Inequality Database, they are able to account for the uncertainty of the estimated Gini coefficients. They find that the results are sensitive to the choice of country sample, time period, and inequality measure.

Berggren (1999), focusing on property rights, finds that from 1975 to 1985 , the more a country increased its economic freedom, the more equality it had at the end of the period. Trade liberalization and financial deregulation were the most important areas of economic freedom for reducing inequality. He also finds that increasing economic freedom slowly seems to result in more equality.

For the United States, there are various ways of measuring income and what counts as income. Different measures of income provide different measures of inequality. According to Rose (2018), "all studies find that income inequality rose after 1979, but the

\footnotetext{
1 A Gini coefficient, or index, measures the degree of dispersion of a variable. It ranges from a value of zero to one, with a higher coefficient representing greater inequality. For income, a Gini coefficient of zero demonstrates equal distribution (all individuals have the same income), and a Gini coefficient of one occurs when all income is possessed by one individual (the case of maximal inequality).
} 
common perception that all income gains went to the top 10 percent and that middle class incomes stagnated (or even declined) are wrong."

Ashby and Sobel (2008) use cross-sectional data for US states from 1980 to 2003 and confirm Berggren's (1999) result that reforms matter. Specifically, the authors confirm Berggren's result that the coefficients are negative and significant. They also find that increasing economic freedom increases everyone's income, but the top quintile gains about twice as much as the lowest quintile. Their analysis considers the impact of economic freedom on the lowestincome quintile in three different models: the cumulative percentage change in the mean income within the lowest quintile from 1980 to 2003; the middle-quintile income level at the end of the period (2001-2003); and the share of total income held by the lowest quintile. For all models, the effect of economic freedom is positive and significant.

Compton, Giedeman, and Hoover (2014) also use state-level economic freedom measures to look at how changes in economic freedom affect state-level income growth across income quintiles. They find that the lowest-income quintile does not benefit from increasing economic freedom. Thus, increasing economic freedom leads to greater inequality.

Apergis, Dincer, and Payne (2014) find two interesting relationships. First, causation may run in the opposite direction: states with higher inequality adopt more-redistributive policies, which lowers their economic freedom score. Second, in the long run, the decline in economic freedom further increases income inequality. Hoover, Compton, and Giedeman (2015) use state-level data from 1980 to 2010 to examine the impact of economic freedom on the racial income gap. They find evidence that higher state-level economic freedom is correlated with a larger gap in median income between black households and white households.

Feldmann $(2007,2010)$ demonstrates that increases in economic freedom tend to reduce unemployment. While this relationship isn't directly linked to income inequality, the literature shows a link between income inequality and unemployment: the lack of income in times of unemployment contributes substantially to increased income inequality (Jenkins 1995; Mocan 1999). In this way, increases in economic freedom can lead to reductions in unemployment, which then reduces income inequality. 
Many of the results regarding economic freedom and income equality are contradictory. The literature supporting the positive impact of economic freedom on economic growth is fairly settled, however. Ultimately, growth is good for the poor (Dollar and Kraay 2002), and the ideas of economic liberalism are effective tools in the pursuit of economic development to pull the poorest among us out of poverty (Williamson 2017).

\section{Conclusion}

Social justice concerns some of the most important social problems of our time. Persecution of minorities, political inequality, and economic inequality are well-known problems that have existed throughout human history. Modern societies pride themselves on having alleviated many of these problems, yet they still persist throughout the world, including many parts of the developed world.

But crucial for seeking to further alleviate these social problems is understanding how they might be improved. While the ends may never justify the means, it is important to understand whether particular means lead to particular ends. Economic freedom is usually not in the vocabulary of social justice advocates. If anything, when economic freedom is mentioned in the context of social justice, it is considered to be in opposition to the movement's goals. But, as the research we have summarized suggests, the term should be part of the advocates' vocabulary.

Economic freedom is not a panacea for the world problems that the social justice movement is concerned with. But it may solve or at least mitigate some of them. Where it is does not solve a problem, we should also be interested in whether economic freedom exacerbates a problem or is merely unrelated to it. By gaining a better understanding of the academic research on the relationship between social justice and economic freedom, we can move beyond slogans and simple theories toward solving real social problems. As John Maynard Keynes (1926, p. 311) writes,

The political problem of mankind is to combine three things: economic efficiency, social justice, and individual liberty. The first needs criticism, precaution, and technical knowledge; the second, an unselfish and enthusiastic spirit, which loves the ordinary man; the third, tolerance, breadth, appreciation of the excellencies of variety and independence, which prefers, above everything, to give 
unhindered opportunity to the exceptional and to the aspiring.

If Lord Keynes is right about the political problem of mankind, then the political problem of mankind may well be restated as needing to advance the economic freedom of the world. We agree with Craig and Goodman (2019) with a slight modification: economic liberalism is essential for social justice.

\section{References}

Aixala, Jose, and Gema Fabro. 2009. "Economic Freedom, Civil Liberties, Political Rights and Growth: A Causality Analysis." Spanish Economic Review, 11(3): 16578.

Apergis, Nicholas, Oguzhan Dincer, and James E. Payne. 2014. "Economic Freedom and Income Inequality Revisited: Evidence from a Panel Error Correction Model." Contemporary Economic Policy, 32(1): 67-75.

Ashby, Nathan J., and Russell S. Sobel. 2008. "Income Inequality and Economic Freedom in the US States." Public Choice, 134 (3-4): 329-46.

Bell, Lee Anne. 2016. "Theoretical Foundations for Social Justice Education.” In Teaching for Diversity and Social Justice, ed. Maurianne Adams and Lee Anne Bell, 3-26. New York: Routledge.

Bennett, Daniel L., and Boris Nikolaev. 2017. "Economic Freedom \& Happiness Inequality: Friends or Foes?” Contemporary Economic Policy, 35(2): 373-91.

Berggren, Niclas. 1999. "Economic Freedom and Equality: Friends or Foes?" Public Choice, 100(3-4): 203-23.

Berggren, Niclas, and Henrik Jordahl. 2006. "Free to Trust: Economic Freedom and Social Capital." Kyklos, 59(2): 141-69.

Berggren, Niclas, and Therese Nilsson. 2013. "Does Economic Freedom Foster Tolerance?" Kyklos, 66(2): 177-207.

Berggren, Niclas, and Therese Nilsson. 2014. "Market Institutions Bring Tolerance, Especially Where There Is Social Trust." Applied Economics Letters, 21(17): 1234-37.

Berggren, Niclas, and Therese Nilsson. 2016. "Tolerance in the United States: Does Economic Freedom Transform Racial, Religious, Political and Sexual Attitudes?" European Journal of Political Economy, 45(December): 53-70.

Bergh, Andreas, and Therese Nilsson. 2010. "Do Liberalization and Globalization Increase Income Inequality?” European Journal of Political Economy, 26(4): 488505.

Bernstein, Jared, Elizabeth C. McNichol, Lawrence Mishel, and Robert Zahradnik. 2000. Pulling Apart: A State-by-State Analysis of Income Trends. Washington, DC: Center on Budget and Policies Priorities, and Economic Policy Institute.

Bjørnskov, Christian. 2003. "The Happy Few: Cross-Country Evidence on Social Capital and Life Satisfaction." Kyklos, 56(1): 3-16.

Bjørnskov, Christian. 2018. "The Hayek-Friedman Hypothesis on the Press: Is There an Association between Economic Freedom and Press Freedom?" Journal of Institutional Economics, 14(4): 617-38.

Buonanno, Paolo, Daniel Montolio, and Paolo Vanin. 2009. "Does Social Capital Reduce Crime?” Journal of Law and Economics, 52(1): 145-70. 
Carter, John R. 2007. "An Empirical Note on Economic Freedom and Income Inequality.” Public Choice, 130(1-2): 163-77.

Cigler, Allan, and Mark R. Joslyn. 2002. "The Extensiveness of Group Membership and Social Capital: The Impact on Political Tolerance Attitudes." Political Research Quarterly, 55(1): 7-25.

Clark, J. R., and Robert Lawson. 2008. "The Impact of Economic Growth, Tax Policy, and Economic Freedom on Income Inequality." Journal of Private Enterprise, 23(3): 23-31.

Compton, Ryan A., Daniel C. Giedeman, and Gary A. Hoover. 2014. "A Distributional Analysis of the Benefits of Economic Freedom." European Journal of Political Economy, 33(March): 121-33.

Costa, Dora L., and Matthew E. Kahn. 2003. "Civic Engagement and Community Heterogeneity: An Economist's Perspective." Perspectives on Politics, 1(1): 10311.

Cowen, Tyler, and Alex Tabarrok. 2018. Modern Principles: Microeconomics. 4th ed. Worth Publishers.

Craig, Alexander W., and Nathan Goodman. 2019. "Social Capital and Social Justice: Why Liberalism Is Essential." Journal of Private Enterprise, 34(1): 59-73.

Dawson, John W. 1998. "Institutions, Investment, and Growth: New CrossCountry and Panel Data Evidence.” Economic Inquiry, 36(4): 603-19.

De Soysa, Indra. 2016. "Capitalism \& the 'New Wars': Free Markets and Societal Insecurity before and after the Cold War, 1970-2013." Civil Wars, 18(1): 1-24.

De Soysa, Indra, and Hanne Fjelde. 2010. "Is the Hidden Hand an Iron Fist? Capitalism and Civil Peace, 1970-2005." Journal of Peace Research, 47(3): 287-98.

De Soysa, Indra, Tor Georg Jakobsen, and Marthe Holum. 2017. "Free-Market Capitalism, Interpersonal Trust, and Trust in Political Institutions: A Multilevel Empirical Analysis, 1994-2014." Journal of Globalization Studies, 8(2): 3-13.

De Soysa, Indra, and Krishna Chaitanya Vadlammanati. 2013. "Do Pro-Market Economic Reforms Drive Human Rights Violations? An Empirical Assessment, 1981-2006." Public Choice, 155(1-2): 163-87.

De Soysa, Indra, and Krishna Chaitanya Vadlamannati. 2017. "Does Social Diversity Impede Sound Economic Management? An Empirical Analysis, 1980-2012." Social Science Research, 62(February): 272-90.

Devereux, Stephen, J. Allister McGregor, and Rachel Sabates-Wheeler. 2011. "Introduction: Social Protection for Social Justice." IDS Bulletin, 42(6): 1-9.

Dollar, David, and Aart Kraay. 2002. "Growth Is Good for the Poor." Journal of Economic Growth, 7(3): 195-225.

Feldmann, Horst. 2007. "Economic Freedom and Unemployment around the World." Southern Economic Journal, 74(1): 158-76.

Feldmann, Horst. 2010. "Economic Freedom and Unemployment." In Economic Freedom of the World 2010 Annual Report, ed. James Gwartney, Joshua Hall, and Robert Lawson, 187-201. Vancouver: Fraser Institute.

Feldmann, Horst. 2017. "Economic Freedom and Human Capital Investment." Journal of Institutional Economics, 13(2): 421-45.

Friedman, Milton. 1962. Capitalism and Freedom. Chicago: University of Chicago Press.

Gehring, Kai. 2013. "Who Benefits from Economic Freedom? Unraveling the Effect of Economic Freedom on Subjective Well-Being." World Development, 50(October): 74-90. 
Goel, Rajeev K., and Michael A. Nelson. 2005. "Economic Freedom versus Political Freedom: Cross-Country Influences on Corruption." Australian Economic Papers, 44(2): 121-33.

Graeff, Peter, and Guido Mehlkop. 2003. "The Impact of Economic Freedom on Corruption: Different Patterns for Rich and Poor Countries." European Journal of Political Economy, 19(3): 605-20.

Grubel, Herbert G. 1998. "Economic Freedom and Human Welfare: Some Empirical Findings." Cato Journal, 18(2): 287-304.

Gwartney, James, Robert Lawson, Joshua Hall, and Ryan Murphy. 2018. Economic Freedom of the World: 2018 Annual Report. Vancouver: Fraser Institute.

Hayek, Friedrich A. 1944. The Road to Serfdom. Chicago: University of Chicago Press.

Hayek, Friedrich A. 1976. Law, Legislation, and Liberty. Vol. 2, The Mirage of Social Justice. Chicago: University of Chicago Press.

Heller, Lauren R., Robert A. Lawson, Ryan H. Murphy, and Claudia R. Williamson. 2018. "Is Human Trafficking the Dark Side of Economic Freedom?" Defence and Peace Economics, 29(4): 355-82.

Hoover, Gary A., Ryan A. Compton, and Daniel C. Giedeman. 2015. “The Impact of Economic Freedom on the Black/White Income Gap." American Economic Review, 105(5): 587-92.

Inglehart, Ronald. 1999. "Trust, Well-Being and Democracy." In Democracy and Trust, ed. Mark E. Warren, 88-120. Cambridge: Cambridge University Press.

International Labour Organization. 2017. "40 Million in Modern Slavery and 152 Million in Child Labour Around the World.” Ilo.org.

Jackson, Jeremy J. 2017a. "Economic Freedom and Social Capital: Pooled Mean Group Evidence.” Applied Economics Letters, 24(6): 370-73.

Jackson, Jeremy. 2017b. "Free to Be Happy: Economic Freedom and Happiness in US States." Journal of Happiness Studies, 18(4): 1207-29.

Jackson, Jeremy, Art Carden, and Ryan A. Compton. 2015. "Economic Freedom and Social Capital." Applied Economics, 47(54): 5853-67.

Jackson, Jeremy, and Jeffrey Palm. 2017. "The Limits of Redistribution and the Impossibility of Egalitarian Ends." Independent Review, 22(1): 71-81.

Jenkins, Stephen P. 1995. "Accounting for Inequality Trends: Decomposition Analyses for the UK, 1971-86." Economica, 62(245): 29-63.

Kawachi, Ichiro, Sankaran Venkata Subramanian, and Daniel Kim. 2008. "Social Capital and Health: A Decade of Progress and Beyond." In Social Capital and Health, ed. Ichiro Kawachi, Sankaran Venkata Subramanian, and Daniel Kim, 1-26. New York: Springer.

Keynes, John Maynard. 1926. "Liberalism and Labour" in Essays in Persuasion. Reprinted 2009. Scotts Valley, CA: CreateSpace Independent Publishing

Knack, Stephen, and Philip Keefer. 1997. "Does Social Capital Have an Economic Payoff? A Cross-Country Investigation.” Quarterly Journal of Economics, 112(4): 1251-88.

Kymlicka, Will. 1995. Multicultural Citizenship: A Liberal Theory of Minority Rights. Oxford: Clarendon Press.

Lawson, Robert A., and Jeff R. Clark. 2010. "Examining the Hayek-Friedman Hypothesis on Economic and Political Freedom." Journal of Economic Behavior \& Organization, 74(3): 230-39. 
Lederman, Daniel, Norman Loayza, and Ana Maria Menendez. 2002. "Violent Crime: Does Social Capital Matter?" Economic Development and Cultural Change, 50(3): 509-39.

Miller, Terry, Anthony B. Kim, and James M. Roberts. 2018. 2018 Index of Economic Freedom. Washington, DC: Heritage Foundation.

Mocan, H. Naci. 1999. "Structural Unemployment, Cyclical Unemployment, and Income Inequality." Review of Economics and Statistics, 81(1): 122-34.

Navia, Patricio, and Thomas D. Zweifel. 2003. "Democracy, Dictatorship, and Infant Mortality Revisited." Journal of Democracy, 14(3): 90-103.

Nikolaev, Boris. 2014. "Economic Freedom and Quality of Life: Evidence from the OECD's Your Better Life Index.” Journal of Private Enterprise, 29(3): 61-96.

Nikolaev, Boris, and Daniel L. Bennett. 2017. "Economic Freedom and Emotional Well-Being." Journal of Regional Analysis \& Policy, 47(1): 88-99.

Nussbaum, Martha. 2000. Women and Human Development: The Capabilities Approach. Cambridge: Cambridge University Press.

Persell, Caroline Hodges, Adam Green, and Liena Gurevich. 2001. "Civil Society, Economic Distress, and Social Tolerance." Sociological Forum, 16(2): 203-30.

Rawls, John. 1971. A Theory of Justice. Harvard University Press.

Rawls, John. 2001. Justice as Fairness: A Restatement. Cambridge, MA: Belknap.

Rose, Stephen. 2018. "How Different Studies Measure Income Inequality: Piketty and Saez Are Not the Only Game in Town." Washington, DC: Urban Institute.

Saha, Shrabani, and Jen-Je Su. 2012. "Investigating the Interaction Effect of Democracy and Economic Freedom on Corruption: A Cross-Country Quantile Regression Analysis." Economic Analysis and Policy, 42(3): 389-96.

Sandholtz, Wayne, and William Koetzle. 2000. "Accounting for Corruption: Economic Structure, Democracy, and Trade." International Studies Quarterly, 44(1): 31-50.

Scully, Gerald W. 2002. "Economic Freedom, Government Policy and the TradeOff between Equity and Economic Growth." Public Choice, 113(1-2): 77-96.

Sen, Amartya. 1989. "Development as Capability Expansion." Journal of Development Planning, 19(1): 41-58.

Simpson, George Eaton, and J. Milton Yinger. 1985. Racial and Cultural Minorities: An Analysis of Prejudice and Discrimination, 5th ed. New York: Plenum.

Stansel, Dean, José Torra, and Fred McMahon. 2018. Economic Freedom of North America 2018. Vancouver: Fraser Institute.

Stiglitz, Joseph, Amartya Sen, and Jean-Paul Fitoussi. 2009. Report by the Commission on the Measurement of Economic Performance and Social Progress. City: Commission on the Measurement of Economic and Social Progress.

Stolle, Dietlind, Stuart Soroka, and Richard Johnston. 2008. "When Does Diversity Erode Trust? Neighborhood Diversity, Interpersonal Trust and the Mediating Effect of Social Interactions." Political Studies, 56(1): 57-75.

Sullivan, John L., James Piereson, and George E. Marcus. 1993. Political Tolerance and American Democracy. Chicago: University of Chicago Press.

Sullivan, John L., and John E. Transue. 1999. "The Psychological Underpinnings of Democracy: A Selective Review of Research on Political Tolerance, Interpersonal Trust, and Social Capital." Annual Review of Psychology, 50(1): 62550 . 
Thoms, Oskar N. T., and James Ron. 2007. "Do Human Rights Violations Cause Internal Conflict?” Human Rights Quarterly, 29(3): 674-705.

Tomasi, John. 2012. Free Market Fairness. Princeton, NJ: Princeton University Press.

Unterhalter, Elaine. 2012. Gender, Schooling and Global Social Justice. London: Routledge.

Veenhoven, Ruut. 2000. "Freedom and Happiness: A Comparative Study in FortyFour Nations in the Early 1990s." In Culture and Subjective Well-Being, ed. Edward Diener and Eunkook Suh, 257-88. Cambridge, MA: MIT Press.

Williamson, Claudia R. 2017. "Praise for Property." Journal of Private Enterprise, 32(4): 83-94.

Wu, Wenbo, and Otto A. Davis. 1999. "The Two Freedoms, Economic Growth and Development: An Empirical Study.” Public Choice, 100(1-2): 39-64. 